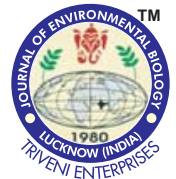

\title{
A study on concentration of total petroleum hydrocarbons in lentic water bodies near oil field areas of upper Assam, India
}

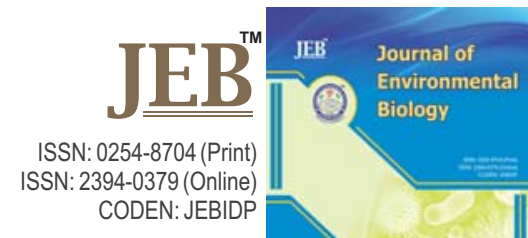

Authors Info

B. Basumatary ${ }^{1}$, M. K. Das ${ }^{2 *}$, S. Baishya and S. Bordoloi

${ }^{1}$ Department of Botany, North Lakhimpur College (Autonomous), Lakhimpur-787 031, India

${ }^{2}$ Resource Management and Environment Section, Life Sciences Division, Institute of Advanced Study in Science and Technology, Guwahati-781 035, India

${ }^{*}$ Corresponding Author Email : das_mk08@rediffmail.com

Key words

Lentic water body,

Oil fields,

Petroleum hydrocarbons

Publication Info

Paper received : 09.09.2015

Revised received : 23.02 .2016

Re-revised received : 22.07 .2016

Accepted: 13.09 .2016
Abstract

Aim: Contamination of water and soil by crude oil and their accumulation in biota as a result of exploration, production, maintenance, transportation, storage and accidental release, add hazardous chemicals to the ecosystem. To determine the spatial and temporal variations of total petroleum hydrocarbon (TPH) concentrations in water, sediment and plant samples, a study was conducted in ten selected lentic water bodies in and around oil fields, group gathering stations and oil collecting stations of upper Assam, India.

Methodology: The samples (water, sediment and plant) were collected seasonally during June, 2013 to May, 2014. Water samples were collected from the surface in amber colored glass bottles. The sediment samples were collected from $15-30 \mathrm{~cm}$ depth below the water surface with soil sampler from three points $(1 / 4,1 / 2$ and $3 / 4)$ across the lentic water bodies in sterile polythene bags. Aquatic plant samples were uprooted, carefully separated from the soil and rinsed. The samples were transported to the laboratory in ice boxes under low temperature conditions and TPH extraction was done by standard methods. The extracted samples from water, sediment and plants were analysed for TPH in Gas Chromatography.

Results: Results showed that both water and sediments contained significant $(p<0.05)$ concentration of TPH ranging between 89 to $843 \mathrm{mg} \mathrm{I}^{-1}$ and 9843.35 to $59194.48 \mathrm{mg} \mathrm{kg}^{-1}$ respectively. The collected plants also showed the presence of significant $(p$ $<0.05)$ concentration of TPH in shoot ( 295 to $872 \mathrm{mg} \mathrm{kg}^{-1}$ ) and in root (178 to $617 \mathrm{mg} \mathrm{kg}^{-1}$ ).

Interpretation: The TPH concentration in water, sediments and plants were relatively higher during the post monsoon season compared to winter and monsoon seasons. The TPH content in plants varied considerably with species.
Hydrocarbon pollution liberated from industrial activity and accumulated in the lentic water bodies
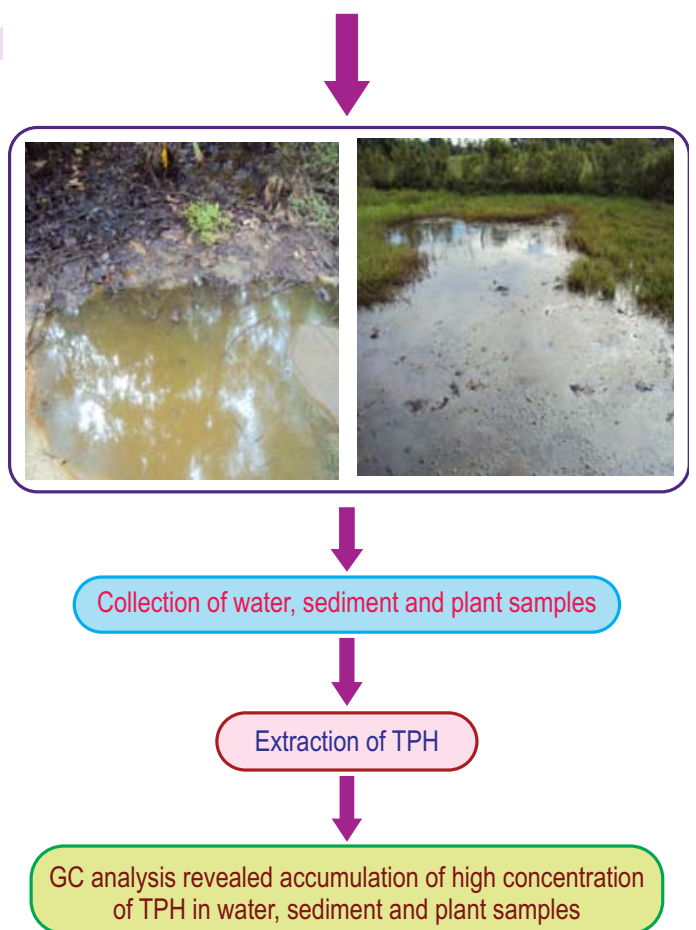


\section{Introduction}

Contamination of water and sediments with petroleum hydrocarbons is a serious problem of global scale, primarily in countries that produce, transport and refine oil. The major ecological problems associated with the oil industry are pollution derived from oil drilling, transportation and refinery wastes which finally reach the aquatic systems. The contamination of the environment by petroleum hydrocarbons is becoming a rising environmental concern. Petroleum hydrocarbons have a widespread distribution in the environment and the carcinogenicity and mutagenicity of several of these compounds have already been proved (Koyano et al., 2001; Liu and Korenga, 2001; Simko, 2002; Basumatary et al., 2012). Oil spillage as a result of natural activities like oozing out, eruptions or anthropogenic activities like exploration, production, maintenance, storage, accidental release, spillage, refining, transportation etc. is of serious concern in environment, as well as to the living organisms (Basumatary et al., 2012; Dahlmann and Kienhuis, 2015; Yavari et al., 2015; Nyankson et al., 2016).

Water and sediment are two major sinks for toxicants which can be correlated with petroleum hydrocarbons. Sedimentbound toxicants create an exposure risk for benthic organisms that can bioaccumulate through ingestion of sediment-dwelling taxa by predators, direct exposure to dissolved and particular forms in core and surface waters and uptake by plants and algae (Roberts et al., 2006).

With increasing pressure from rapid urban developments, increasing petroleum exploration and refining, there is a risk of adverse impacts of toxic substances to waterways and aquatic ecosystems. Hydrocarbon inputs in the present study sites in upper Assam, India include drilling, industry, effluent discharge, oil spill and natural oozing out etc. To determine the amount of total petroleum hydrocarbons in the lentic water bodies in and around oil fields, refinery sites, group gathering stations etc., an assessment was conducted in ten selected sites of upper Assam focusing on the TPH accumulation in water, sediments and plants.

\section{Materials and Methods}

Study area : Different lentic water bodies in and around oil fields of Digboi (Tinsukia district), Duliajan, Naharkatia (Dibrugarh district) were surveyed to study the effect of hydrocarbon pollution on plants and sediments. Samples were collected during monsoon (June, July, August), post monsoon (September, October, November) and winter (December, January, February) seasons. The study area covered 10 different locations namely site 1 (27022'57.64" and 95038'19.33") $1.5 \mathrm{~km}$ distance from Digboi Refinery, site 2 ( $27^{\circ} 20^{\prime} 70.8^{\prime \prime}$ and 95'28'99.6") $0.1 \mathrm{~km}$ distance from Jorajan oil collecting station, site 3 (DuliajanNaharkatia road side $27^{\circ} 21^{\prime} 06.4^{\prime \prime}$ and $95^{\circ} 28^{\prime} 90.5^{\prime \prime}$ ) away from oil collecting station and drilling sites, site 4 (Nagarjan: 27034'57.2" and $95^{\circ} 48^{\prime} 67.1^{\prime \prime)} 1 \mathrm{~km}$ distance from oil collecting station, site 5 (Naharkatia, Moumari: 27019'59.3" and 95018'25.5") $1 \mathrm{~km}$ distance from group gathering station, site 6 (Naharkatia, Bahdhery: 27018'69.0" and 95018'87.9") $1.1 \mathrm{~km}$ distance from oil collecting station, site 7 (Naharkatia, Merbeel: 27018'78.0" and 95017'31.9") $1.3 \mathrm{~km}$ distance from oil pipeline joints, site 8 (Digboi-Duliajan road side pond: $27^{\circ} 38^{\prime} 64.1^{\prime \prime}$ and 9561'32.4") 0.5 $\mathrm{km}$ distance from oil pipeline joints (pipeline leakage), site 9 (Duliajan: 27019'36.24" and 95018'18.53") near pipeline leakage and site 10 (Near OCS Digboi: 27035'61.9" and 9552'85.4") 1.14 $\mathrm{km}$ distance from oil collecting station.

Three surveys were made for sample collection in every season. In each survey, five samples were collected randomly from each sampling location.

Sample collection and analysis : Water samples were collected from the surface in amber colored glass bottles and were transported to the laboratory in ice boxes under low temperature conditions. For assessment of hydrocarbon, extractions from water samples were carried out with $20 \mathrm{ml}$ of $\mathrm{n}$-hexane in a separating funnel. The process was repeated thrice so that a concentrated extract is obtained. The water extracts were dried by anhydrous sodium sulphate and the extracts were concentrated by rotary evaporation (EPA 3510C, 1992). The sediment samples were collected from $15-30 \mathrm{~cm}$ depth below the water surface with soil sampler from three points (1/4, 1/2 and $3 / 4)$ across the lentic water bodies in sterile polythene bags. The samples collected in the polythene bags were transported to the laboratory in ice box under low temperature conditions. Pebbles, shells and plant materials were removed and the samples were air dried. Soil was ground and sieved (mesh size $2 \mathrm{~mm}$ ). The total organic carbon (TOC) content in the sediment was determined by modified Walkley-Black method (Sahrawat, 1982).

Analysis of TPH was carried out by the modified EPASW846 Method 8270B, (USEPA, 1994) utilizing an automated accelerated solvent extractor (Dionex ASE-200) with 100\% dichloromethane. The extracted TPH was collected and immediately concentrated to a volume of $1 \mathrm{ml}$. Five replicates were analyzed from each sample.

Aquatic plant samples were collected by uprooting. Roots were carefully separated from the soil, rinsed, and carried to the laboratory under low temperature condition. Plant samples were washed thoroughly with deionised water to remove the soil materials. Plants were separated into roots and shoots and chopped before homogenizing with a blender. Roots and shoots of different plants were then separately extracted in carbon tetrachloride by solvent extractor (Atagana, 2011) for studying TPH contents.

The extracted samples from water, sediment and plant samples were analysed for TPH by Gas Chromatography (GC 
Agilent $6890 \mathrm{~N}$ fitted with a flame ionizer detector). An HP- 5 column from Agilent $6890 \mathrm{~N}$ with length $15 \mathrm{~m}$, inner diameter $0.53 \mathrm{~mm}$ and film thickness $1.5 \mu \mathrm{m}$ was used to separate TPH from carrier gas (helium flowing at a rate of $7 \mathrm{ml} \mathrm{min}{ }^{-1}$ ). The temperature of the oven was increased from $140^{\circ} \mathrm{C}$ to $170^{\circ} \mathrm{C} @ 2^{\circ} \mathrm{C}$ per min, maintained at $170^{\circ} \mathrm{C}$ for $5 \mathrm{~min}$, and later increased to $280^{\circ} \mathrm{C}$ at $30^{\circ} \mathrm{C}$ per min and maintained at $280^{\circ} \mathrm{C}$ for $10 \mathrm{~min}$. The temperature of the injector was $280^{\circ} \mathrm{C}$ and that of the detector was $300^{\circ} \mathrm{C}$.

Statistical analysis : Statistical analysis was carried out with SPSS 18.0 for Windows. TPH concentration in water, sediments and plants were subjected to one way analysis of variance (ANOVA) to test significant difference between different sites and seasons $(p<0.05)$. In case of linear data, Tukey's HSD was performed. In the case where data were heterogeneous and not distributed normally, Kruskal-Wallis test was used. Linear regression was done in order to find out the degree of correlation between TPH in water, sediments and plants, and between TPH and TOC concentrations in sediments.

\section{Results and Discussion}

During the study period, average $\Sigma T P H$ concentration in water ranged between 89 to $843 \mathrm{mg} \mathrm{l}^{-1}$ with a median value of 58.33 to $652.33 \mathrm{mg} \mathrm{l}^{-1}$ (Table 1). Temporal variation of the average values of $\Sigma T P H$ concentration in water samples ranged from 80.33 to $218 \mathrm{mg} \mathrm{l}^{-1}$ in monsoon, 530 to $843 \mathrm{mg} \mathrm{l}^{-1}$ in post monsoon and 158 to $452 \mathrm{mg} \mathrm{l}^{-1}$ in winter (Table 3). However, the temporal average $\Sigma$ TPH concentration in water showed significantly $(p<$ 0.05 ) high during the post monsoon season. In winter season average $\Sigma T P H$ concentration was lower than post monsoon season. Monsoon season showed the lowest average $\Sigma T P H$ concentration in water samples. The average concentrations of $\Sigma T P H$ in water samples of monsoon, post monsoon and winter seasons were found to be beyond the permissible limit of Bureau of Indian Standards (BIS, 2012) for inland surface water of class $\mathrm{A}\left(0.2 \mu \mathrm{g} \mathrm{l} \mathrm{I}^{-1}\right)$. Class $\mathrm{A}$ represents the drinking water source without

Table 1 : Spatial variation of median and average values of TPHs concentration in water. Values represent mean of five replicates and significant difference at $p<0.05$

\begin{tabular}{lll}
\hline Sites & Mean $\left(\mathrm{mgl}^{-1}\right)$ & Median $\left(\mathrm{mg} \mathrm{I}^{-1}\right)$ \\
\hline I & 843 & 652.33 \\
II & 665.10 & 581.66 \\
III & 89 & 58.33 \\
IV & 360.22 & 406 \\
V & 342.32 & 406.66 \\
VI & 311.22 & 252.33 \\
VII & 302.88 & 262 \\
VIII & 249.77 & 328 \\
IX & 518.88 & 456 \\
X & 293.66 & 273.33 \\
All sites & 450.50 & 417.66 \\
\hline
\end{tabular}

conventional treatment but after disinfection (BIS, 2012). In sediment samples, the spatial average $\Sigma T P H$ concentration ranged between 9843.35 to $59194.48 \mathrm{mg} \mathrm{kg}^{-1}$ with a median value ranging from 9803 to $56510 \mathrm{mg} \mathrm{kg}^{-1}$ (Table 2). Similarly, the temporal average $\Sigma T P H$ concentration ranged between 4543 to $25459 \mathrm{mg} \mathrm{kg}^{-1}$ in monsoon, 15949 to $59194 \mathrm{mg} \mathrm{kg}^{-1}$ in post monsoon and 8988 to $36934 \mathrm{mg} \mathrm{kg}^{-1}$ in winter (Table 4). For sediment sample also the average $\Sigma T$ PH concentration was found to be significantly $(p<0.05)$ higher during the post monsoon season and lowest during the monsoon season. In each sampling site, the average concentration of $\Sigma T P H$ in sediments were found several times higher than the average content in water. The reason for lower concentration of $\Sigma T P H$ in water as compared to sediments may be due to low aqueous solubility, volatilization, and affinity of these compounds to organic matter (Malik et al., 2011). Moreover, hydrocarbon contents in the dissolved phase could be reduced by photolysis and aerobic biodegradation process which are not available to sediments (Shi et al., 2005). Since these compounds are hydrophobic, they are accumulated at the bottom sediments, particulate matter and biota (Kirso et al., 2001).

The results showed highest median, as well as average concentration of $\Sigma T P H s$ at site 1 in both water and sediments followed by 2 and 9 . Sites 4, 5, 6, 7, 8 and 10 showed slightly lower $\Sigma T P H$ than the above sites. Site 1 is located approximately $1.5 \mathrm{~km}$ away from the Digboi refinery, site 2 is located nearest to the oil collecting station and site 9 is located nearest to the oil pipeline joints. Site 3 showed lowest concentration of $\Sigma T P H s$ which is located away from refinery and drilling sites. Higher concentration of $\Sigma$ TPHs near the refinery and drilling area may be ascribed to washing down from upstream oil field sites, refineries and urban areas or natural oozing in these areas. Malik et al., (2011) found that higher concentration of polycyclic aromatic hydrocarbons (PAHs) near the urban area may be ascribed to greater atmospheric fallout of $\mathrm{PAH}$-enriched particles near the combustion sources, augmented by inputs from erosion, transport, and redisposition of sediments containing combustion derived PAHs.

Table 2 : Spatial variation of median and average values of TPHs concentration in sediments. Values represent mean of five replicates and significant at $p<0.05$

\begin{tabular}{lll}
\hline Sites & Mean $\left(\mathrm{mg} \mathrm{kg}^{-1}\right)$ & Median $\left(\mathrm{mg} \mathrm{kg}^{-1}\right)$ \\
\hline I & 59194.48 & 56510 \\
II & 46285 & 45270 \\
III & 9843.35 & 9803 \\
IV & 33239 & 33303 \\
V & 35470.12 & 35481 \\
VI & 31150 & 31127 \\
VII & 26415 & 26403 \\
VIII & 33779 & 33659 \\
IX & 48862.55 & 46819 \\
X & 28593 & 28632 \\
All sites & 35415 & 34470 \\
\hline
\end{tabular}


In water and sediment samples, the $\Sigma$ TPHs concentration relation between all the sites was relatively complex, not showing any considerable spatial or temporal gradient. Average $\Sigma T P H$ concentration in water samples was significantly $(p<0.05)$ high during the post monsoon season. Concentration trend of $\Sigma T P H s$ was not consistent from post monsoon to winter season at different sites. However, in both water and sediments of lentic water body, average concentration of $\Sigma T P H s$ (average of all sites) was observed to be highest during the post monsoon season and lowest during the monsoon. Doong and Lin (2004), Agarwal et al. (2006) and Malik et al. (2011) also found similar results in their study for water and sediments, where a significant correlation existed between the decrease in $\Sigma T$ TPHs in water and sediment with surface runoff. This seasonal variation could be attributed to the surface runoff reaching the lentic water bodies. During monsoon season, surface runoff had diluted impact on the water body, thereby resulting in lower concentration of $\Sigma$ TPHs in water, whereas in the post monsoon season, increase in the concentration of $\Sigma$ TPHs may be attributed to less dilution due to reduced rainfall.
In the present study, higher levels of $\Sigma T P H s$ could be recorded at ten study sites as per permissible limit of BIS (2012). This might pose a risk to maintain ecosystem health. In freshwater sediments, Pettigrove and Hoffmann (2005) derived a threshold concentration of $860 \mathrm{mg} \mathrm{kg}^{-1}$ based on field microcosm experiments using freshwater invertebrates and synthetic motor oils $(C>16)$. They found that hydrocarbon concentrations of 860 $\mathrm{mg} \mathrm{kg}^{-1}$ dry weight hydrocarbons altered community structure and chironomid abundances, while concentrations above 1,858 mg $\mathrm{kg}^{-1}$ significantly impaired taxa richness and abundance (Pettigrove and Hoffmann, 2005). The most recent review of sediment quality guidelines by Simpson et al. (2010) proposed a TPH threshold concentration as low as $275 \mathrm{mg} \mathrm{kg}^{-1}$ and as high as $960 \mathrm{mg} \mathrm{kg}^{-1}$ based on the available literature and these have been adopted for this study.

$\Sigma T P H$ concentrations in sediments collected during the study was above $4500 \mathrm{mg} \mathrm{kg}^{-1}$ and exceeded the proposed threshold value of $275 \mathrm{mg} \mathrm{kg}^{-1}$ proposed by Simpson et al., (2010). It is possible that hydrocarbons could have been washed down from upstream oil field sites, refineries and urban areas or

Table 3: Temporal variation of average values of TPHs concentration in water

\begin{tabular}{llll}
\hline Sites & Monsoon $\left(\mathrm{mgl}^{-1}\right)$ & Post monsoon $\left(\mathrm{mgl}^{-1}\right)$ & Winter $\left(\mathrm{mgl}^{-1}\right)$ \\
\hline I & $218 \pm 9$ & $843 \pm 10$ & $452 \pm 8$ \\
II & $124 \pm 9$ & $689 \pm 9$ & $281 \pm 7$ \\
III & $80.33 \pm 7$ & $530 \pm 9$ & $158 \pm 8$ \\
IV & $208.80 \pm 7$ & $766.66 \pm 10$ & $406 \pm 8$ \\
V & $201 \pm 9$ & $718 \pm 9$ & $406.66 \pm 9$ \\
VI & $105 \pm 6$ & $636 \pm 9$ & $252 \pm 7$ \\
VII & $89 \pm 7$ & $617 \pm 10$ & $262 \pm 7$ \\
VIII & $92 \pm 7$ & $629 \pm 8$ & $328 \pm 8$ \\
IX & $119 \pm 8$ & $781 \pm 8$ & $356 \pm 8$ \\
X & $175 \pm 9$ & $582.33 \pm 8$ & $273.33 \pm 9$ \\
All sites & $141 \pm 7$ & $679 \pm 9$ & $317 \pm 8$ \\
\hline
\end{tabular}

Values represent mean of five replicates and significant at $p<0.05$

Table 4 : Temporal variation of average values of TPHs concentration in sediments

\begin{tabular}{llll}
\hline Sites & Monsoon $\left(\mathrm{mg} \mathrm{kg}^{-1}\right)$ & Post monsoon $\left(\mathrm{mg} \mathrm{kg}^{-1}\right)$ & Winter $\left(\mathrm{mg} \mathrm{kg}^{-1}\right)$ \\
\hline I & $25459 \pm 20$ & $59194 \pm 20$ & $36934 \pm 18$ \\
II & $23449 \pm 18$ & $53174 \pm 20$ & $32232 \pm 20$ \\
III & $4543 \pm 15$ & $15949 \pm 15$ & $8988 \pm 17$ \\
IV & $21338 \pm 20$ & $49316 \pm 20$ & $29064 \pm 20$ \\
V & $22226 \pm 19$ & $53174 \pm 18$ & $31011 \pm 20$ \\
VI & $17126 \pm 20$ & $49022 \pm 20$ & $27304 \pm 18$ \\
VII & $12766 \pm 18$ & $42849 \pm 19$ & $23630 \pm 16$ \\
VIII & $18473 \pm 17$ & $52799 \pm 20$ & $30066 \pm 20$ \\
IX & $21781 \pm 20$ & $58945 \pm 20$ & $35860 \pm 20$ \\
X & $14825 \pm 15$ & $44762 \pm 20$ & $26192 \pm 18$ \\
All sites & $18199 \pm 18$ & $47918 \pm 18$ & $28128 \pm 20$ \\
\hline
\end{tabular}

Values represent mean $\pm \mathrm{SD}$ of five replicates and significant at $p<0.05$ 
Table 5 : Spatial variations of median and average values of TPHs concentration in plant shoots and roots

\begin{tabular}{llccc}
\hline \multirow{2}{*}{ Plants } & \multicolumn{2}{c}{ Shoot $\left(\mathbf{m g ~ k g}^{-1}\right)$} & \multicolumn{2}{c}{ Root $\left(\mathbf{m g ~ k g}^{-1}\right)$} \\
\cline { 2 - 3 } & Mean & Median & Mean & Median \\
\hline Cyperus difformis & 295.79 & 304.81 & 262.56 & 245.22 \\
Cyperus esculentus & 504.66 & 476.05 & 368.86 & 356.85 \\
Cyperus helferi & 316.77 & 295.79 & 245.82 & 231.36 \\
Cyperusiria & 401.32 & 374.19 & 273.34 & 257.25 \\
Cyperus scariosus & 745.76 & 718.18 & 512.28 & 499.84 \\
Cyperus cyperoides & 596.10 & 571.48 & 398.43 & 375.78 \\
Cyperus brevifolius & 553.38 & 521.82 & 373.58 & 336.37 \\
Cyperus odoratus & 506.79 & 476.24 & 392.67 & 373.39 \\
Cyperus laevigatus & 458.28 & 430.38 & 376.08 & 353.65 \\
Cyperus rotundus & 669.11 & 650.13 & 334.94 & 408.81 \\
\hline
\end{tabular}

Values represent mean of five replicates and significant at $p<0.05$

Table 6: Temporal variation of average values of TPHs concentration in plant shoot and root

\begin{tabular}{|c|c|c|c|c|c|c|}
\hline \multirow[t]{2}{*}{ Plants } & \multicolumn{2}{|c|}{ Monsoon ( $\mathrm{mg} \mathrm{kg}^{-1}$ ) } & \multicolumn{2}{|c|}{ Postmonsoon ( $\left.\mathrm{mg} \mathrm{kg}^{-1}\right)$} & \multicolumn{2}{|c|}{ Winter $\left(\mathrm{mg} \mathrm{kg}^{-1}\right)$} \\
\hline & Shoot & Root & Shoot & Root & Shoot & Root \\
\hline Cyperus rotundus & $304 \pm 15$ & $186 \pm 20$ & $455 \pm 20$ & $356 \pm 16$ & $375 \pm 16$ & $245 \pm 19$ \\
\hline Cyperus laevigatus & $476 \pm 20$ & $317 \pm 16$ & $655 \pm 15$ & $484 \pm 20$ & $561 \pm 18$ & $376 \pm 20$ \\
\hline Cyperus odoratus & $295 \pm 18$ & $222 \pm 18$ & $479 \pm 12$ & $386 \pm 17$ & $358 \pm 16$ & $281 \pm 16$ \\
\hline Cyperus brevifolius & $374 \pm 19$ & $178 \pm 15$ & $565 \pm 17$ & $383 \pm 20$ & $455 \pm 17$ & $257 \pm 15$ \\
\hline Cyperus cyperoides & $718 \pm 20$ & $419 \pm 18$ & $872 \pm 18$ & $617 \pm 19$ & $800 \pm 20$ & $499 \pm 16$ \\
\hline Cyperus scariosus & $571 \pm 15$ & $311 \pm 20$ & $823 \pm 20$ & $508 \pm 20$ & $645 \pm 20$ & $375 \pm 18$ \\
\hline Cyperus iria & $521 \pm 13$ & $275 \pm 18$ & $686 \pm 17$ & $450 \pm 15$ & $616 \pm 15$ & $336 \pm 18$ \\
\hline Cyperus helferi & $476 \pm 14$ & $282 \pm 17$ & $661 \pm 20$ & $503 \pm 20$ & $552 \pm 18$ & $373 \pm 20$ \\
\hline Cyperus esculantus & $430 \pm 19$ & $292 \pm 20$ & $605 \pm 20$ & $482 \pm 20$ & $514 \pm 17$ & $353 \pm 19$ \\
\hline Cyperus difformis & $650 \pm 16$ & $362 \pm 20$ & $852 \pm 18$ & $533 \pm 17$ & $707 \pm 20$ & $408 \pm 14$ \\
\hline
\end{tabular}

Values represent mean of five replicates and significant at $p<0.05$

local roads. Subsequent concentrations have exceeded the high threshold, and this may be or concern for the bottom feeding organisms and detritivores.

The contamination of hydrophobic organic compounds in sediments is dependent on the chemical properties of the ecosystem, the partition coefficients of individual compounds, and the organic contents of sediment particles (McKenize-Smith et al., 1994). Under steady state, distribution of PAHs is expected to follow equilibrium partitioning of the PAHs to sediment organic carbon (Simpson et al., 1996). Distribution for $\Sigma \mathrm{TPHs}$ concentration generally followed that of TOC content in the sediment samples of lentic water body. This is reflected through significant $(p<0.05)$ correlation $\left(R^{2}\right)$ obtained between TOC and $\Sigma$ TPHs contents in different seasons: $R^{2}=0.648$ for monsoon, $R^{2}=$ 0.753 for post monsoon and $R^{2}=0.735$ for winter season (Fig. 1). The poor correlation during monsoon might be due to relative seasonal changes.

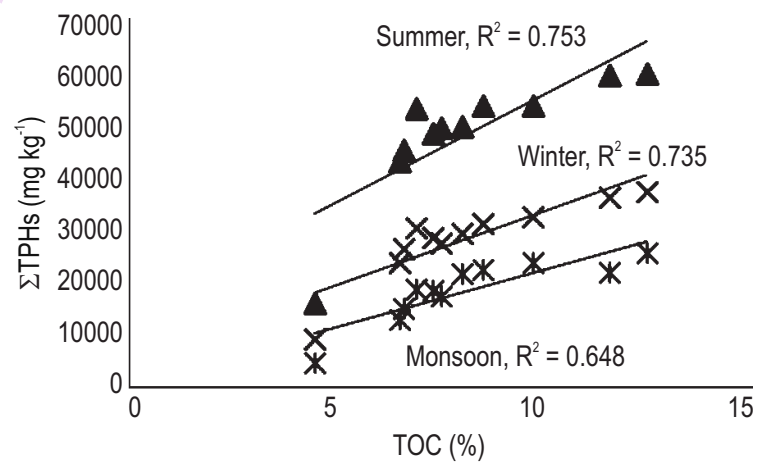

Fig. 1 : Correlation between $\Sigma$ TPHs and TOC (\%) in the sediment. Values represent mean \pm SD of five replicates and significant at $p<0.05$

The study revealed that plants, specially belonging to Cyperaceae family showed significant concentration of $\Sigma \mathrm{TPH}$ in shoots and roots (Table 5). These plants were found to be growing 
abundantly at the study sites. The spatial average values of $\Sigma T P H s$ in shoots ranged from 295.79 to $745.76 \mathrm{mg} \mathrm{kg}^{-1}$ with median value ranging from 295 to $718.18 \mathrm{mg} \mathrm{kg}^{-1}$. In roots the $\Sigma T P H s$ concentration ranged from 245.82 to $512.28 \mathrm{mg} \mathrm{kg}^{-1}$. The median value of root ranged from 231.36 to $499.84 \mathrm{mg} \mathrm{kg}^{-1}$. The spatial $\Sigma$ TPHs concentration was highest in the plant body of Cyperus scariosus (shoot: $754.76 \pm 47.76 \mathrm{mg} \mathrm{kg}^{-1}$; root $512.28 \pm$ $87.15 \mathrm{mg} \mathrm{kg}^{-1}$ ) followed by Cyperus rotundus (shoot: $669.11 \pm$ $32.87 \mathrm{mg} \mathrm{kg}^{-1}$; root: $434.94 \pm 88.41 \mathrm{mg} \mathrm{kg}^{-1}$ ), Cyperus cyperoides (shoot: $596.10 \pm 42.65 \mathrm{mg} \mathrm{kg}^{-1}$; root: $398.43 \pm 100 \mathrm{mg} \mathrm{kg}^{-1}$ ), Cyperus brevifolius (shoot: $553.38 \pm 54.66 \mathrm{mg} \mathrm{kg}^{-1}$; root: $373.58 \pm$ $120.64 \mathrm{mg} \mathrm{kg}^{-1}$ ), Cyperus odoratus (shoot: $506.79 \pm 44.25 \mathrm{mg} \mathrm{kg}$ ; root: $392.67 \pm 84.26 \mathrm{mg} \mathrm{kg}{ }^{-1}$ ), Cyperus esculentus (shoot: $504.66 \pm 49.55$; root: $368.86 \pm 15.14 \mathrm{mg} \mathrm{kg}^{-1}$ ), Cyperus laevigatus (shoot: $458.28 \pm 48.32$; root: $376.08 \pm 96.91 \mathrm{mg} \mathrm{kg}^{-1}$ ), Cyperus iria (shoot: $401.32 \pm 46.99$; root: $273.34 \pm 103.53 \mathrm{mg} \mathrm{kg}$ ' ${ }^{1}$ ), Cyperus difformis (shoot: $328.27 \pm 40.63$; root: $262.56 \pm 86.09$ $\mathrm{mg} \mathrm{kg}^{-1}$ ) and Cyperus helferi (shoot: $316.77 \pm 36.34$; root: 245.82 $\pm 83.51 \mathrm{mg} \mathrm{kg}^{-1}$ ). However, the TPHs content in shoot was relatively higher than in root in all the plant species studied. The $\Sigma$ TPH concentration in plant shoot and root was significantly $(p<$ 0.05 ) higher during the post monsoon season in comparison to winter and monsoon seasons in all the plant species studied.

In monsoon, temporal variation of $\Sigma \mathrm{TPH}$ in plant shoots ranged from 295 to $718 \mathrm{mg} \mathrm{kg}^{-1}$ and that of root was 178 to $419 \mathrm{mg}$ $\mathrm{kg}^{-1}$ in monsoon (Table 6). In post monsoon, $\Sigma$ TPH ranged from 455 to $872 \mathrm{mg} \mathrm{kg}^{-1}$ in shoots and 356 to $613 \mathrm{mg} \mathrm{kg}^{-1}$ in roots while that of winter ranged from 358 to $800 \mathrm{mg} \mathrm{kg}^{-1}$ in shoots and 245 to $499 \mathrm{mg} \mathrm{kg}^{-1}$ in roots. The $\Sigma$ TPH content in plant species was found to be species dependent. This accumulation might be due to the reason that water soluble low molecular weight hydrocarbons become bioavailable for plants to be taken up.

Spatial and temporal trend in the concentration levels of TPHs in plants could not be observed. During post monsoon, $\Sigma T P H$ concentration reached maximum level and showed significant differences $(p<0.05)$ and in monsoon $\Sigma$ TPH concentration was lower. This could possibly be due to dilution of surface water, due to run off water reaching in this water bodies. This is similar to the findings of Kirso et al. (2001) and Malik et al. (2011). Shoots showed more accumulation of TPH in comparison to roots. The uptake of TPH by these higher plants was found to be very selective. However, it can be inferred that the plants found in the studied site have significant concentration of $\Sigma \mathrm{TPH}$ in shoots and in roots.

The results of the present study indicated that water, sediment and plants of lentic water bodies near oil fields and refinery sites showed TPH content and accumulated petroleum hydrocarbons. $\Sigma T P H$ in water, sediments and plants exceeded the permissible limits of BIS and WHO. The levels of TPH at these sites may pose a risk to the health of aquatic flora and fauna. Therefore, remediation of hydrocarbon from these sites is necessary so that contamination of TPH will not spread to contiguous ecosystem.

\section{Acknowledgments}

The research has been supported by Government of India, Ministry of Development of North Eastern Region, North Eastern Council Secretariat, Nongrim Hills, Shillong-792003, Meghalaya, India. The authors gratefully acknowledge the infrastructural facility provided by the Director, IASST, Guwahati781035, Assam, India.

\section{References}

Agarwal, T., P.S. Khillare and V. Shridha: PAHs contamination in bank sediment of the Yamuna river, Delhi, India. Environ. Monit. Assess., 123, 151-166 (2006).

Atagana, H.I.: The potential of Chromolaena odorata $(L)$ to decontaminate used engine oil impacted soil under greenhouse conditions. Int. J. Phytoremed., 13, 627-641 (2011).

Basumatary, B., R. Saikia and S. Bordoloi: Phytoremediation of crude oil contaminated soil using nut grass, Cyperus rotundus. J. Environ. Biol., 33, 891-896 (2012).

Basumatary, B., R. Saikia, S. Bordoloi, H.C. Das and H.P. Sarma: Assessment of potential plant species for phytoremediation of hydrocarbon-contaminated areas of upper Assam. J. Chem. Technol. Biotechnol., 87, 1329-1334 (2012).

B.I.S.: Indian standards: Tolerance limits for inland surface waters subject to pollution (2296-1982). New Delhi: IS (2012).

Dahlmann, G. and P. Kienhuis: Oil spill sampling and the bonn-oil spill identification network: A common method for oil spill identification. 44. In oil pollution in the North Sea. The Handbook Environ. Chemi., 44, 237-254 (2015).

Doong, R. and Y. Lin: Characterization and distribution of polycyclic aromatic hydrocarbon contaminations in surface sediment and water from Gao-ping River, Taiwan. Water Res., 38, 1733-1744 (2004).

E.P.A. 3510C: Semivolatile and Nonvolatile Organics. Office of research and Development USEPA, Cincinnati, Ohio (1992).

Kirso, U., L. Paalme, M. Voll, N. Irha and E. Urbas: Distribution of the persistent organic pollutants, polycyclic aromatic hydrocarbons, between water, sediments and biota, Aquat. Ecosyst. Hith. Manag., 4, 151-163 (2001).

Koyano, K., S. Mineki, Y. Tsunoda, O. Endo, T. Goto and T. Tadahiro: Effect of fish (mackerel pike) broiling on polycyclic aromatic hydrocarbon contamination of suspended particulate matter in indoor air. J. Hlth. Sci., 47, 452-459 (2001).

Liu, X. and T. Korenga: Dynamic analysis for the distribution of polycyclic aromatic hydrocarbons in rice. J. Health Sci., 47, 446-451 (2001).

Malik, A., P. Verma, A.K. Singh and K.P. Singh: Distribution of polycyclic aromatic hydrocarbons in water and bed sediments of the Gomti River, India., Environ. Monit. Assess., 172, 529-545. (2011).

McKenize-Smith, F., D. Tiller and D. Allen: Organochlorine pesticide residues in water and sediments from the Ovens and King rivers, north-east Victoria, Australia. Arch. Environ. Contam. Toxicol., 26, 483-490 (1994).

Nyankson, H., D. Rodene and R.B. Gupta: Advancements in crude oil spill remediation research after the deepwater horizon oil spill. 
Water Air Soil Poll. Online first 227-229 (January 2016). DOI: 10.1007/s11270-0155-2727-5.

Pettigrove, V. and A. Hoffmann: A field-based microcosm method to assess the effects of polluted urban stream sediments on aquatic macroinvertebrates. Environ. Toxicol. Chem., 24, 170-180 (2005).

Roberts, D.A., A.G.B. Poore and E.L. Johnston: Ecological consequences of copper contamination in macroalgae: Effects on epifauna and associated herbivores. Environ. Toxicol. Chem., 25, 2470-2479 (2006)

Sahrawat K.L.: Simple modification of the Walkley-Black method for simultaneous determination of organic carbon and potentially mineralizable nitrogen in tropical rice soils. Plant Soil, 69, 73-77 (1982).

Shi, Z., S. Tao, B. Pan, W. Fan, X.C. He and Q. Zuo: Contamination of rivers in Tianjin, China by polycyclic aromatic hydrocarbons. Environ. Pollut., 134, 97-111. (2005).
Simko, P. : Determination of polycyclic aromatic hydrocarbons in smoked meat products and smoke flavouring food additives. J. Chromatogr. B., 770, 3-18. (2002).

Simpson, C.D., A.A. Mosi , W.R. Cullen and K.J. Reimer: Composition and distribution of polycyclic aromatic hydrocarbon contamination in surficial marine sediments from Kitimat Harbor, Canada. Sci. Total Environ., 181, 265-278 (1996).

Simpson, S.L., G.E. Batley and A.A. Chariton: Revision of the ANZECC andARMCANZ sediment quality guidelines. Prepared for the Department of the Environment, Water, Heritage and Arts. CSIRO Land and Water 279 Science Report 08/07. (2010).

USEPA : United States Environmental Protection Agency, Test Methods for Evaluating Solid and Hazardous Waste. USEPA, Washington, DC (1994).

Yavari S., A. Malakahmad and N.B. Sapari: A review on phytoremediation of crude oil spills. Water Air Soil Poll., 226-279 (2015). DOI: $10.1007 /$ s $11270-015-2550-z$. 